\title{
KAJIAN AWAL PEMBUATAN BIODIESEL DARI MINYAK DEDAK PADI DENGAN PROSES ESTERIFIKASI
}

\author{
Aprilina Purbasari ${ }^{*}$ dan Silviana \\ Jurusan Teknik Kimia Fakultas Teknik UNDIP Semarang \\ Jl. Prof. Soedarto, SH, Tembalang, Semarang 50239, Telp.(024)7460058 \\ ${ }^{*}$ Penulis korespondensi: aprilinap@yahoo.com
}

\begin{abstract}
Abstrak
Biodiesel merupakan bahan bakar alternatif yang dapat dibuat dari minyak nabati melalui proses transesterifikasi, esterifikasi, atau esterifikasi-transesterifikasi dengan alkohol. Minyak dedak padi merupakan salah satu minyak nabati yang mengandung asam lemak bebas tinggi. Pada penelitian ini minyak dedak padi diesterifikasi dengan pelarut methanol. Minyak kemudian diekstraksi dengan menggunakan etanol sebagai solven. Variabel operasi proses esterifikasi adalah suhu reaksi (40; 50; $\left.60^{\circ} \mathrm{C}\right)$ dan konsentrasi $\mathrm{HCl}$ sebagai katalis $(0,5 ; 1 ; 1,5 ; 2 ; 2,5 \%-v)$ Hasil penelitian menunjukkan bahwa konversi asam lemak bebas menjadi ester meningkat seiring meningkatnya suhu dan katalis. Kondisi optimum adalah $50^{\circ} \mathrm{C}$ dengan 1,5\%-v katalis dimana konversi asam lemak bebas yang diperoleh sebesar 78,33\% dan konsentrasi metil ester pada produk sebesar76,89\%.
\end{abstract}

Kata kunci: asam lemak bebas, biodiesel, esterifikasi, metanol, minyak dedak padi

\begin{abstract}
Biodiesel is a promising alternative fuel which can be made from vegetable oil by trans-etherification, etherification, or etherification-trans etherification process with alcohol. Rice bran oil, one of vegetable oils having high content of free fatty acid, was etherified with methanol in this research. The oil was extracted from rice bran by using methanol as the solvent. The operating variables of the etherification process were temperature $\left(40 ; 50 ; 60^{\circ} \mathrm{C}\right)$ and concentration of $\mathrm{HCl}$ as catalyst for the reaction $(0.5 ; 1 ; 1.5 ; 2 ; 2.5 \%-v)$. The experimental results show that conversion of fatty acid to ether increase as temperature and concentration of the catalyst increase. The optimum condition is $50^{\circ} \mathrm{C}$ with 1,5\%-v catalyst, in which the conversion fatty acid is $78.33 \%$ and concentration of methyl ester in the product mixture is $76.89 \%$.
\end{abstract}

Keywords: biodiesel, etherification, free fatty acid, methanol, rice bran oil

\section{PENDAHULUAN}

Dedak merupakan produk samping penggilingan gabah menjadi beras. Penggilingan satu ton gabah menghasilkan dedak sebanyak $60-80 \mathrm{~kg}$. Bergantung pada varietas beras dan derajat penggilingannya, dedak padi mengandung 16-32\%-b minyak. Sekitar 60-70\% minyak dedak padi tidak dapat digunakan sebagai bahan makanan (non-edible oil) dikarenakan kestabilan dan perbedaan cara penyimpanan dedak padi (Goffman et al., 2003).

Minyak dedak padi merupakan salah satu jenis minyak berkandungan gizi tinggi karena adanya kandungan asam lemak, komponen-komponen aktif biologis, dan komponen-komponen antioksi seperti oryzanol, tocopherol, tocotrienol, phytosterol, polyphenol, dan squalene (Goffman et al., 2003; Özgul and Türkay, 1993). Dedak padi yang masih baru mengandung asam lemak bebas 4-8\%-b dan kandungan asam lemak bebas ini dapat meningkat secara cepat karena adanya enzim lipase yang aktif dalam dedak padi setelah proses penggilingan. Kandungan asam lemak bebas yang tinggi dan adanya senyawa-senyawa tak tersaponifikasikan mengakibatkan minyak dedak padi sulit dimurnikan dan tidak dapat digunakan sebagai edible oil. Karakteristik dan komposisi asam lemak dalam minyak dedak padi ditunjukkan oleh tabel 1 dan 2 berikut.

Tabel 1. Karaktreristik minyak dedak padi (Adi, 2003)

\begin{tabular}{lc}
\hline \multicolumn{1}{c}{ Karakteristik } & Range \\
\hline Densitas (g/mL) & $0,92-0,925$ \\
\% FFA (asam oleat) & $5-80$ \\
\hline
\end{tabular}


Tabel 2. Komposisi asam lemak dalam minyak dedak padi (Rahmania, 2004)

\begin{tabular}{lc}
\hline \multicolumn{1}{c}{ Jenis Asam Lemak } & Kadar (\%-b) \\
\hline Asam Miristat (C14:0) & 0,3366 \\
Asam Palmitat (C16:0) & 17,2096 \\
Asam Stearat (C18:0) & 1,7112 \\
Asam Oleat (C18:1) & 45,7510 \\
Asam Linoleat (C18:2) & 33,4208 \\
Asam Linolenat (C18:3) & 0,3645 \\
Asam Arachidik (C20:0) & 1,2063 \\
\hline
\end{tabular}

Dengan kadar lemak kurang dari 25\%, cara terbaik untuk mengambil minyak dedak adalah melalui ekstraksi menggunakan pelarut mudah menguap, seperti metanol, heksan, atau IPA. Minyak nabati yang mengandung trigliserida dan atau FFA biasanya diekstrak dengan hexane atau metanol (Kirk and Othmer, 1978). Minyak dedak hasil ekstraksi (minyak dedak mentah) dipisahkan dari pelarut melalui proses penguapan.

Biodiesel merupakan bahan bakar alternatif yang menjanjikan yang dapat dibuat dari minyak nabati, baik minyak baru maupun bekas penggorengan, melalui proses transesterifikasi, esterifikasi, atau esterifikasitransesterifikasi dengan alkohol. Biodiesel bersifat ramah terhadap lingkungan karena biodegradable, nontoxic, dan rendah emisi (Ma et al., 1999).

Biodiesel dapat dibuat dengan proses esterifikasi jika minyak nabati yang digunakan mengandung asam lemak bebas tinggi. Asam lemak bebas dan alkohol dapat dikonversi menjadi ester (biodiesel) dan air dengan katalis asam sesuai reaksi :

$\underset{\text { Asam lemak }}{\mathrm{RCOOH}}+\underset{\text { Metanol }}{\mathrm{CH}_{3} \mathrm{OH} \longleftrightarrow} \underset{\text { Metil ester }}{\mathrm{RCOOCH}_{3}}+\underset{\text { Air }}{\mathrm{H}_{2} \mathrm{O}}$

Adapun mekanisme reaksinya adalah

$$
\begin{aligned}
& \mathrm{R}-\mathrm{COOH}+\mathrm{H}^{+} \rightleftharpoons \mathrm{R}-\mathrm{C}^{\prime \prime} \stackrel{\mathrm{OH}}{+} \stackrel{+\mathrm{R}^{\prime} \mathrm{OH}}{-\mathrm{R}^{\prime} \mathrm{OH}}
\end{aligned}
$$

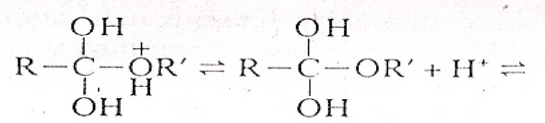

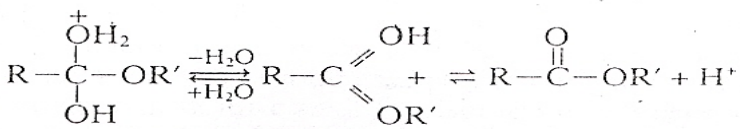

Sedangkan faktor-faktor yang dapat mempengaruhi reaksi esterifikasi antara lain adalah suhu, pengadukan, waktu, dan katalisator.

Pada penelitian ini minyak dedak padi dimanfaatkan sebagai bahan baku pembuatan biodiesel. Kandungan asam lemak bebas yang tinggi dalam minyak dedak padi diubah menjadi metil ester (biodiesel) dengan metanol dan katalis $\mathrm{HCl}$ melalui proses esterifikasi. Tujuan dari penelitian ini adalah untuk mempelajari pengaruh suhu dan penambahan katalis pada proses esterifikasi terhadap konversi biodiesel yang dihasilkan.

\section{METODE PENELITIAN}

Bahan utama yang digunakan dalam penelitian ini adalah dedak padi yang telah disimpan selama 1 bulan agar kandungan asam lemak bebasnya tinggi, metanol, dan $\mathrm{HCl}$. Alat utama yang digunakan adalah soklet, labu leher tiga, pemanas untuk proses ekstraksi serta labu leher tiga, pengaduk, pendingin liebig, pemanas untuk proses esterifikasi.

Percobaan dilakukan dalam 2 tahap, yaitu ekstraksi minyak dedak padi dan reaksi esterifikasi minyak dedak padi. Minyak diekstraksi dari dedak padi dengan pelarut metanol pada suhu $70^{\circ} \mathrm{C}$ selama 2 jam. Minyak dedak padi yang diperoleh mengandung asam lemak bebas 62,21\%. Hasil ekstraksi minyak dedak padi yang masih mengandung metanol dengan perbandingan berat metanol dan asam lemak bebas adalah 3,65 : 1 sebanyak $100 \mathrm{ml}$ kemudian direaksikan dengan katalis $\mathrm{HCl}$ selama 90 menit dan diaduk dengan kecepatan $100 \mathrm{rpm}$ pada kondisi operasi sesuai variabel kajian. Kajian variabel yang dipelajari adalah suhu reaksi $\left(40 ; 50 ; 60^{\circ} \mathrm{C}\right)$ dan jumlah katalis $\mathrm{HCl}(0,5 ; 1 ; 1,5 ; 2 ; 2,5 \%-v)$. Produk hasil esterifikasi kemudian dianalisa kadar asam lemak bebasnya untuk mengetahui konversi yang diperoleh pada masing-masing variabel kajian dan dianalisa GCMS untuk mengetahui metil ester yang terbentuk.

\section{HASIL DAN PEMBAHASAN}

\section{Pengaruh Suhu Terhadap Konversi}

Gambar 1 menunjukkan bahwa semakin tinggi suhu maka konversi yang diperoleh semakin tinggi pula.

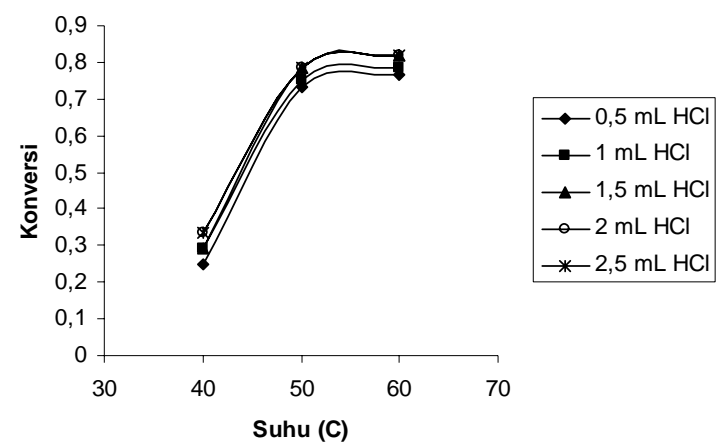

Gambar 1. Hubungan suhu terhadap konversi pada variasi penambahan katalis

Kenaikan suhu mengakibatkan kenaikan aktivitas molekuler sehingga kemungkinan terjadinya tumbukan antara molekul-molekul semakin besar, yaitu antara asam lemak bebas dan metanol dengan adanya katalis asam membentuk metil ester, sehingga 
konversi yang diperoleh semakin meningkat. Pada masing-masing penambahan katalis, kenaikan konversi secara tajam terjadi pada kenaikan suhu dari 40 hingga $50^{\circ} \mathrm{C}$ dan sedikit naik dari suhu 50 hingga $60^{\circ} \mathrm{C}$ sehingga suhu reaksi optimum pada penelitian ini adalah $50{ }^{\circ} \mathrm{C}$.

\section{Pengaruh Penambahan Katalis Terhadap Konversi}

Pengaruh penambahan katalis terhadap konversi yang diperoleh ditunjukkan oleh gambar 2 .

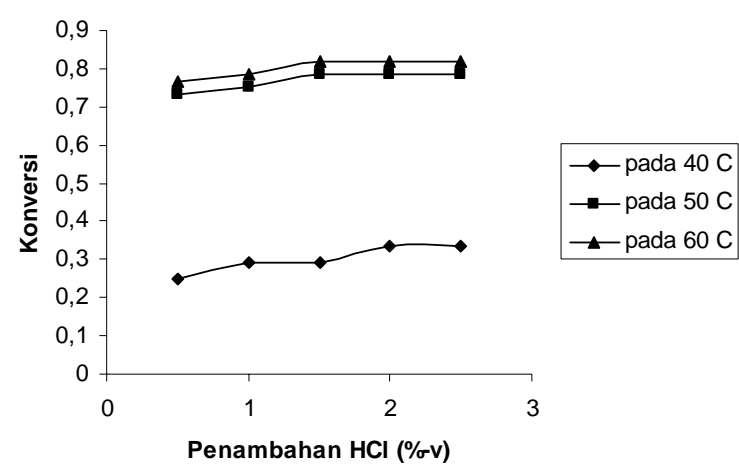

Gambar 2. Hubungan penambahan katalis terhadap konversi pada variasi suhu

Katalis berfungsi untuk menurunkan energi ektivasi sehingga reaksi lebih mudah berlangsung. Pada suhu reaksi 50 dan $60^{\circ} \mathrm{C}$ peningkatan pemakaian katalis dari 0,5 hingga $1,5 \%-\mathrm{v}$ mengakibatkan konversi mengalami sedikit peningkatan dan relatif konstan pada pemakaian 1,5 hingga 2,5\%-v, sedangkan pada suhu reaksi $40^{\circ} \mathrm{C}$ konversi yang relatif konstan diperoleh setelah penambahan katalis $2 \%-\mathrm{v}$. Hal ini disebabkan pada suhu reaksi yang lebih rendah $\left(40^{\circ} \mathrm{C}\right)$ aktivitas molekuler reaktan relatif lebih rendah dibandingkan pada suhu yang lebih tinggi (50 dan $60^{\circ} \mathrm{C}$ ) sehingga untuk mencapai kondisi kesetimbangan pada waktu reaksi yang sama dibutuhkan jumlah katalis yang relatif lebih banyak.

\section{Hasil Analisa GCMS Produk}

Hasil analisa GCMS pada salah satu produk menunjukkan bahwa produk mengandung fatty acid methyl ester (FAME) sekitar 76,89\%.

\section{KESIMPULAN}

Dari hasil penelitian dapat disimpulkan bahwa kenaikan suhu dapat meningkatkan konversi dan peningkatan penambahan katalis hanya sedikit meningkatkan konversi. Konversi optimum sebesar $78,33 \%$ diperoleh pada suhu $50^{\circ} \mathrm{C}$ dan penambahan katalis 1,5\%-v dengan kadar metil ester 76,89\%.

\section{UCAPAN TERIMA KASIH}

Ucapan terima kasih disampaikan kepada Arief Rahman Hakim, Sutra Irawan, dan Annas Puspita Sari yang telah membantu pelaksanaan penelitian ini.

\section{DAFTAR PUSTAKA}

Adi, N., (2003), ”Ekstraksi Minyak dari Dedak Padi dengan Pelarut n-Hexane", Prosiding Seminar Nasional Teknik Kimia Indonesia, Yogyakarta.

Fukuda, H., Kondo, A. and Nonda, H., (2001), "Biodiesel Fuel Production by Transesterification of Oils”, J. Biosci. Bioeng., pp. 405-416.

Goffman, F.D., Pinson, S., and Bergman C., (2003), "Genetic Diversity for Lipid Content and Fatty Acid Profile in Rice Bran”, J. Am. Oil Chem. Soc., pp. 485-490.

Kirk, R.E and Othmer, D.F., (1978), "Encyclopedia of Chemical Technology", 3rd ed., A Willey Interscience Publicatioin, John Wiley and Sons, Inc, New York.

Ma, F. and Hanna, M.A., (1999), "Biodiesel Production : A Review”, Journal Bioresource Technology 70, pp. 1-15.

Ozgul, Y., and Turkay, S., 1993, "In Situ Esterification of Rice Bran Oil with Methanol and Ethanol”, J. Am. Oil Chem. Soc., pp. 145-147.

Rahmania, O., (2004), ”Transesterifikasi Minyak Mentah Dedak Padi Menjadi Biodiesel dengan Katalis Asam”, Thesis Program Pasca Sarjana, Jurusan Teknik Kimia Fakultas Teknologi Industri, Institut Teknologi Sepuluh November, Surabaya. 